\title{
Psychometric properties of Social Rhythm Metric in regular shift employees
}

\section{Propriedades psicométricas da Escala de Ritmo Social em trabalhadores de turno regular}

\author{
Regina Lopes Schimitt, ${ }^{1}$ Talita Zanetti, ${ }^{2}$ Mayara Mayer, ${ }^{3}$ Cristiane Koplin, ${ }^{3}$ Fabiana Guarienti, ${ }^{4}$ Maria Paz Hidalgo ${ }^{5}$ \\ ${ }^{1}$ Psychologist in Master's Degree Program, Postgraduate Program in Medical Sciences, Medical School (FAMED), Universidade Federal do Rio \\ Grande do Sul (UFRGS), Porto Alegre (RS), Brazil \\ 2 Fundação Faculdade Federal de Ciências Médicas de Porto Alegre (FFFCMPA), Porto Alegre (RS), Brazil \\ ${ }^{3}$ Pontifícia Universidade Católica do Rio Grande do Sul (PUCRS), Porto Alegre (RS), Brazil \\ ${ }^{4}$ Universidade Federal do Rio Grande do Sul (UFRGS), Porto Alegre (RS), Brazil \\ ${ }^{5}$ Department of Psychiatry and Legal Medicine, Medical Schoo (FAMED), Universidade Federal do Rio Grande do Sul (UFRGS), Porto Alegre (RS), Brazil
}

\begin{abstract}
Objective: To analyze the psychometric properties of Brazilian version of Social Rhythm Metric-17 and to present the score algorithm in regular shift employees. Method: This is a cross-sectional study. The Social Rhythm Metric assess the regularity of daily life associated to changes in biological rhythms. The scale was applied, during nine days, to 145 employees, $27.6 \%$ male and 72.4\% female, ages between 18 and 60, mean $=36.1(\mathrm{sd}=9.87)$. Mean values were compared using the Student's t-test for independent samples and ANOVA. Factor analysis was performed using principal component analysis; the reliability analysis, through Spearman's correlation. Results: The Student $t$ test didn't reveal any significant difference between sex in IRA $(\mathrm{t}=0.60 ; \mathrm{p}=0.55)$ or ETA $(t=0.67 ; p=0.95)$. The factor analysis showed three components, the first was associated to survival related activities; the second, related to pleasure and work and the third was related to no essential survive activities. Discussion: This version of the Social Rhythm Metric-17 instrument allows to assess an important human zeitgeber, contributing for other studies which can to evaluate the determinant role of social rhythm. Conclusion: The Brazilian version of social rhythm metric 17 presents validity of content and good test-retest reliability.
\end{abstract}

Descriptors: Ownership; Psychometrics; Algorithm; Workers; Circadian rhythm

\section{Resumo}

Objetivo: Analisar as propriedades psicométricas da Escala de Ritmo Social e apresentar o algoritmo para cálculo dos escores em trabalhadores de turno regular. Método: Este estudo tem delineamento transversal. A escala Escala de Ritmo Social, que afere a regularidade de atividades diárias, foi aplicada durante nove dias, em 145 trabalhadores de turno regular, ambos os sexos, 27,6\% sexo masculino e 72,4\% sexo feminino, com idades entre 18 e 60 anos, média $=36,1$ $(s d=9,87)$. A análise da diferença entre as médias foi realizada por meio do teste $t$ de Student para amostras independentes e ANOVA. A análise fatorial foi realizada por meio de análise de componentes principais; a confiabilidade foi analisada através da correlação de Spearman. Resultados: O teste t de Student não revelou diferença significativa entre os sexos para o Indice de Regularidade de Atividades $(t=0,60 ; p=0,55)$ e para o Escore do Total de Atividades $(t=0,67 ; p=0,95)$. Os escores apresentaram uma distribuição gaussiana na amostra estudada. A análise fatorial mostrou que a escala se agrupa em três componentes, o primeiro deles composto pelas atividades mais impositivas e imprescindiveis para a sobrevivência; o segundo relacionado a trabalho e lazer, e o terceiro o das atividades às quais as pessoas podem frequentemente dispensar sem prejuizo de sua sobrevivência. Discussão: Esta versão permite aferição de um importante zeitgeber em humanos, contribuindo para próximos estudos nos quais possa ser avaliado o papel determinante do ritmo social. Conclusão: A Escala de Ritmo Social apresenta validade de conteúdo e boa fidedignidade teste-reteste.

Descritores: Propriedade; Psicometria; Algoritmo; Trabalhadores; Ritmo circadiano

\section{Introduction}

Humans present a rhythmic pattern of circadian behavior that is endogenously determined and synchronized by exogenous factors, the latter referred to as zeitgebers. Zeitgeber is a German term created by Aschoff in the 1970s, whose literal translation is "time donators" ${ }^{1,2}$ Organisms in free course present a rhythmic behavior without the influence of zeitgebers. In humans, the
Submitted: March 2, 2009

Accepted: October 20, 2009

\section{Correspondence}

Regina Lopes Schimitt

Núcleo de Pesquisas $\mathrm{II}-2^{\circ}$ andar, HCPA

Rua Miguel Bauer, 1685

95600-000 Taquara, RS, Brasil

Phone: (+55 51) 3542-2361

E-mail: regreg@tca.com.br; reginalopesschimitt@gmail.com 
circadian pattern cycle in free course is around 25 hours. Under the influence of zeitgebers, the cycle is reduced to approximately 24 hours. The main human zeitgebers are: light, temperature and social cues. ${ }^{3}$

Although since the beginning of chronobiologic science, the studies on mechanisms subject to human circadian rhythms have shown the influence of "social cues" in the synchronization of biological rhythms, seen as a confusion factor on which the ideal scientific rigidity imposed the elimination, to enable isolated studies on the "pure" phenomenon of physiological variables. Although in the 1980s the emphasis was on physical zeitgebers, intersubject and intrasubject differences were observed in the lifestyle regularity that were similar to the circadian amplitude in the sphere of behavior. ${ }^{4}$

In addition, the influence of this regularity on health/disease process began to be discussed, as in the study about the relation between circadian dysfunction and mood disorders. ${ }^{5-10}$ One of the scientific area field, on the etiology of mood disorders, ${ }^{11-15}$ proposed that certain stressing events of life could cause changes in social zeitgebers of vulnerable individuals, altering social rhythms and consequently biological rhythms, provoking somatic symptoms, such as mood disorders, in a cascade effect. Today, both photic and social zeitgebers are known to cause different and measurable effects. ${ }^{16}$

In 1990, investigators from the University of Pittsburgh developed an instrument to quantify social rhythms, the Social Rhythm Metric, or SRM-17, ${ }^{16}$ which has been used in several studies to investigate the impact of lifestyle regularity on young adults, ${ }^{17}$ parents of newborns, ${ }^{18}$ elderly people, ${ }^{19,20}$ patients with mood disorder, ${ }^{16,21}$ anxiety ${ }^{22}$ and stroke patients. ${ }^{23}$

As a clinical instrument, the Social Rhythm Metric has been used in the United States in the therapeutic method referred to as Interpersonal and Social Rhythm Therapy for tracing alterations in daily life regularity of people with bipolar disorder, as there are evidences that reinforced social zeitgebers are the cause of clinical condition improvement in these patients, as observed in the reduced number of recurrences and increased interval between recurrences in patients submitted to this form of treatment. ${ }^{24,25}$

The SRM-17 $7^{4,16,17}$ is a self-applicable scale where the respondent reports, during a certain period, which activities he/she has performed from a group of 15 fixed and two optional activities. In addition, the respondent should provide the time the activities were performed, who they were performed with and the degree of interaction with this person during the activity. The scale pages are arranged as a pad with one page for each evaluated day and one instruction sheet, which, combined, are considered as a single unit for the score calculation. An algorithm was created to establish two main indexes of this scale. The main index is the activity regularity index. The algorithm considers, for calculation effects, all events that occur at least three times a week. The events that occur at a time regularity are referred to as hits. One hit is an activity that contributes to daily regularity because it occurs more than three times a week at the same time or within a range of 45 minutes before or after the time calculated as habitual. If, for instance, one usually has lunch at least three times a week at midday, or within a range of 45 minutes before or after that time, this activity contributes to one's routine regularity, and is then a hit. The weighted average of total hits is the regularity score. Another important index is the ALI (Activity Level Index), which provides the quantity of different activities in which the person was engaged in the evaluated period.

The method ${ }^{26,27}$ to translate and adapt the Social Rhythm Scale to Brazilian Portuguese, named as ERS-17, tried to keep the highest possible equivalence to the original semantic, conceptual and operational levels. The main indexes elaborated by ERS-17 were named Activity Regularity Index (IRA) and Total Score of Activities (ETA). In this study, the social rhythm evaluation was performed with regular shift employees, as well as the analysis of ERS-17 psychometric properties.

\section{Method}

This study is a cross-sectional study whose main outcome is the assessment of psychometric properties of the scale. The project was approved by the Ethics Committee of Hospital de Clínicas de Porto Alegre, under $n^{\circ} 07417$. The team in charge of data collection was comprised of the project investigator plus six undergraduate students of Universidade Federal do Rio Grande do Sul. The participants, of both genders, were recruited through convenience from the staff of Hospital de Clínicas de Porto Alegre, provided that they were between 18 and 60 years old and presented complete fundamental school education level. The exclusion criteria were: difficulties in understanding; work at inverted shift during the data collection period or in the three previous months; pregnancy; father or mother of newborn of less than six months old; recently coming (less than fifteen days before the data collection period) from places with significant time zone difference and Total Score of Activities below 59. The deadline for data collection conclusion was the beginning of daylight saving time, since the phase advance of the rhythm of sleep, which is imposed at that time, changes the phase relationship between this rate and other biological rhythms. The total sample was comprised by 145 workers, demographically distributed as indicated in Table 1. The size of sample follows the criteria proposed by Hair e Reis ${ }^{28-30}$ to multivariated analysis where

\section{Table 1 - Demographic data of total sample}

\begin{tabular}{lc}
\hline \multicolumn{1}{c}{ Characteristics } & Total sample $(\mathbf{n}=\mathbf{1 4 5})$ \\
\hline Age (years) - mean \pm SD & $36.1 \pm 9.87$ \\
Gender $-\mathbf{n}(\%)$ & \\
Male & $40(27.6)$ \\
Female & $105(72.4)$ \\
School education level (years) - & $12.6 \pm 2.69$ \\
mean \pm SD & \\
Work shift $-\mathbf{n}(\%)$ & \\
Morning & $28(19.3)$ \\
Afternoon & $112(77.2)$ \\
Night & $5(3.4)$ \\
BMI (kg/m ${ }^{2}$ ) - mean \pm SD & $25.1 \pm 4.09$ \\
Antidepressant use $-\mathbf{n}$ (\%) & $8(5.5)$ \\
Hypnotic and BZD use $-\mathbf{n}(\%)$ & $5(3.4)$ \\
\hline
\end{tabular}


the number of observations suggested is between five to twenty time the number of questions in the scale. The authors recommend that the $\mathrm{n}$ can be one hundred observations.

The employees were contacted by the team members and invited to participate in the project. The objective and method of the forms utilized in the study were individually explained and the participants were requested to read and sign the Informed Consent Term. The participants answered the following instruments:

- Questionnaire for Anamnesis, Evaluation of Life Habits and Demographic Characteristics, a self-applicable questionnaire of 19 questions utilized at the psychiatric outpatient clinic of Hospital de Clínicas de Porto Alegre to evaluate general health conditions. ${ }^{31}$

- Social Rhythm Scale (ERS-17), the Brazilian version of SRM-17 (Social Rhythm Metric), a self-applicable questionnaire that seeks to identify how many and which are the events of one's daily life that can establish a rhythmic pattern of behavior. The ERS-17 is a list with 15 predetermined activities and blanks for optional inclusion of two other items from the respondent's personal routine. The respondent fills the questionnaire at the end of each day, reporting the time and who the activity was performed with. The two main scale indexes are: Activity Regularity Index (IRA) and Total Score of Activities (ETA).

Regularity is measured through an algorithm that involves the following steps: 1) calculation of mean time at which each activity was performed and its standard deviation; 2) determination of max. and min. limits based on this mean time; 3) data "removal", with exclusion of all values exceeding limits of \pm 1.5 standard deviation; 4) Recalculation of the mean time at which each activity was performed, using only data within the established limits. This is the habitual time of each activity; 5) calculation of min. and max. time limits of regular activities for the determination of hits. So far, no satisfactory translation of this concept has been provided. Even the term "recurrence", defined in Brazilian Aurélio dictionary as "periodic or frequent reappearance of a fact or phenomenon", does not explain the concept nature, which also involves a time dimension, as every event that can establish a rhythm; 6) calculation of $n$, i.e., the number of activities that occurred at least three times a week. If, based on the 17 activities, only 10 occurred three times a week, then $n$ will be 10;7) count of hits, the activities that occurred within the established time limits; 8) regularity score calculation by dividing the number of hits by $n$. The score ranges from 0 (no regularity) to 9 (total regularity), as in this study the algorithm was adjusted to a nine-day period (refer to Appendix I).

The Total Score of Activities is provided by counting the activities performed during the evaluated period, with minimum acceptable value of 59 (as 0 would represent total inactivity) and maximum value as the maximum quantity of activities divided by the maximum quantity of days. In this study, the ERS- 17 was developed to evaluate a period of at least 9 days, include two periods at rest, such as weekends, and enable reliability tests, while the original version was developed to evaluate a period of at least 7 days. For the nine-day period, the max. value is $153(9 \mathrm{x} 17)$.

The algorithm utilized in the scale score calculation was applied according to the appendix of Monk et al. ${ }^{16}$ and Frank et al., ${ }^{24}$ adjusted to a nine-day period. The instrument author contributed with clarifications of personal communication. Data were entered in Microsoft ${ }^{\circledR}$ Excel 2000 spreadsheets, and based on them, all calculations were made (refer to Appendix I).

The categorical variables are described as frequency, mode and proportions, and the continuous variables as mean and standard deviation. The comparisons of mean values were performed using the Student's t-test for independent samples and ANOVA. The scale score distributions are demonstrated through histogram and skewness calculation. The study of scale components was performed using the Factor Analysis with varimax rotation, and the reliability analysis through Spearman's correlation. The statistical analysis was performed using the Statistical Package for the Social Sciences (SPSS Inc., Chicago, United States), version 12.0. ${ }^{32}$

\section{Results}

The total sample was comprised by 145 workers of Hospital de Clínicas de Porto Alegre (40 men, 105 women). Mean age was 36 years ( $(\mathrm{d}=9.87$ : ranging from 18 to 60 years) and school education level: 12.6 years $(\mathrm{sd}=2.69)$. Among total employees, $28(19.3 \%)$ perform their work activities in the morning shift; $112(77.2 \%)$ in the afternoon shift and $5(3.4 \%)$ in the night shift, the latter considered as ending at 11:30 pm, as employees on night duty were not included.

No significant difference between genders was observed for the Activity Regularity Index (Student's t-test $=0.60 ; \mathrm{p}=0.55$ ) and Total Score of Activities (Student's t-test $=0.67 ; \mathrm{p}=0.95$ ). The difference from the comparison of mean Activity Regularity Indexes was not significant $(F=2.311 ; \mathrm{p}=0.103)$, and no significant difference was observed when comparing the three groups in terms of Total Score of Activities $(F=0.26 ; \mathrm{p}=0.77)$.

Appendix I shows the formulas and the algorithm. Both scores of IRA (skewness $=0.12$ ) and ETA (skewness $=-0.5$ ) present normal distribution in the studied population (Figures 1 and 2). The regularity of activities presented mean of $4.2(\mathrm{sd}=1.28)$,

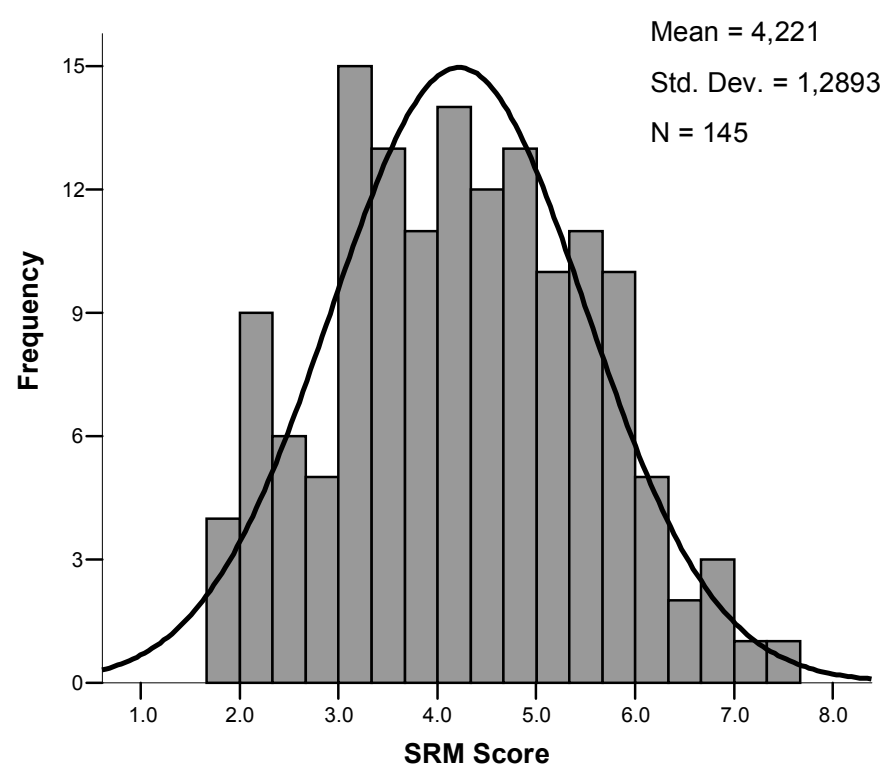

Figure 1 - Distribution curve of rhythmicity scores 


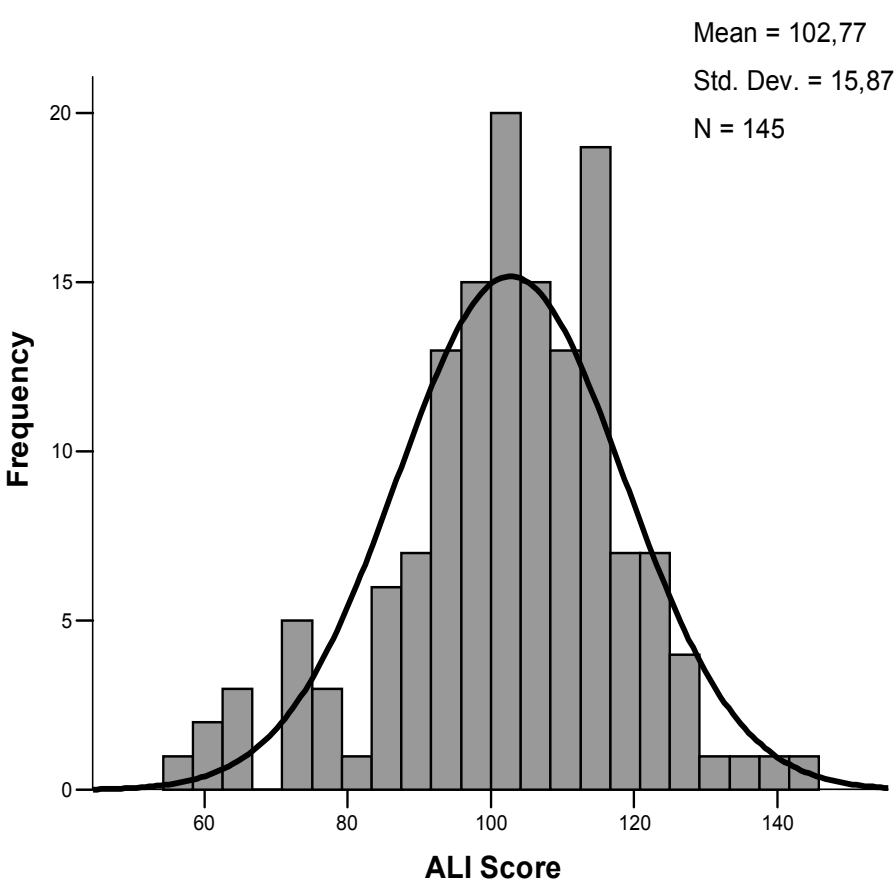

Figure 2 - Distribution curve of Total Score of Activities

ranging from min. 1.8 and max. 7.5 , and activity quantity of 102.8 $(s d=15.87)$. Table 2 shows the analysis results.

The mean value of the activity quantity that occurred at least three times a week (" $n$ ") was $13 \pm 1.67$.

In the descriptive analysis can be observed that the activity with the highest contribution to the regularity index was "I had lunch", mean $=6.3(\mathrm{sd}=1.9)$. However, the activities with the highest mode were: "I took a nap in the afternoon" (mode = 7); "I went to bed" (mode = 7); "I spoke with another person for the first time (personally or on the telephone)" (mode = 6); "Last time I arrived home" (mode = 6) and again "I had lunch" (mode $=5)$ - Table 3 .

The factor analysis showed that three components, the first was associated to survival related activities; the second, related to pleasure and work and the third was related to activities which are no essential to survive. This analysis showed a different result from the English version, which revealed two major factors, one dominated by morning events, the other by afternoon/evening events. The stronger variable that composed the first component is comprised by following questions:"I got out of bed"; "I listened to the radio or watched TV (at home, in the car, at work or somewhere else)"; "The first time I left home"; "I made physical exercises (walk, gymnastics, dance, etc)"; "I had lunch"; "Last time I arrived home" and "I had dinner" (Table 4).
A significant correlation $(r=0.338 ; \mathrm{p}<0.001)$ was obtained when comparing the activity regularity indexes of the first 4,5 days and the last 4,5 days, and an even more significant correlation $(r=0.759 ; \mathrm{p}<0.001)$ was obtained when comparing the total scores of activities in the two periods, indicating a satisfactory test-retest reliability.

\section{Discussion}

For this study, 145 employees of Hospital de Clínicas de Porto Alegre participated, comprising a homogeneous sample for this first phase of Social Rhythm Scale application. Although it increases the internal validation of the study, it will be required to apply it to different groups of patients to increase the external validation and the clinical applicability with the analysis of diagnostic parameters of the instrument (sensitivity, specificity and predictive values). The sample was predominantly comprised of women, which could have caused a sampling bias. However, the analysis showed no difference when comparing genders and IRA and ETA indexes, probably because the scale does not discriminate activity typically performed by men and women or because they were people following the same work schedule, at the same institution, where household chores and children care do not have a great impact. Anyway, this result confirms previous studies ${ }^{3}$ with American samples that did not show any difference when comparing genders.

The school education level in years ( $\mathrm{md}=12.6$ years) does not reflect the Brazilian social reality, where the mean value of school years for people above 10 years, old is 5.7 years, ${ }^{33}$ which probably contributed to the scale answer, similar to studies conducted with the English version of the instrument, where the samples were predominantly comprised of university students. ${ }^{16,17}$ Another item related to the sample homogeneity is the non-inclusion of employees into the night shift; in this study, only 5 (3.4\%) people work in the night shift, considered as ending at 11:30 pm, which therefore, did not characterize a night shift.

Both IRA and ETA presented higher scores than those of American samples in which IRA ranged from $3.40(\mathrm{sd}=0.81)$ to $3.9(\mathrm{sd}=0.83)$ and ETA ranged from $80.20(\mathrm{sd}=6.35)$ to $83(\mathrm{sd}=8.4) .{ }^{3,16-18}$ However, none of these studies presented such a homogeneous sample, as in this study. The difference between North American and Brazilian samples on IRA may be related to the fact that the Brazilian subjects are workers with probably more rigid schedules of work. Moreover, the higher scores presented in ETA should be explained by the difference in the length of the time assessed. Most of the studies evaluate seven days and, in the present study the period of evaluation was nine days. Nevertheless, mean of 13 for the number of activities that occurred at least three times a week was similar to that found in a study with the original instrument in English. ${ }^{16}$

Table 2 - Descriptive analysis of Social Rhythm Scale-17 (ERS-17) scores

\begin{tabular}{cccccc}
\hline \multicolumn{1}{c}{ Scores } & Variation & Mean \pm SD & Median & Min. & Max. \\
& & & (P25-P75) & 142 \\
\hline Total Score of Activities & $59-153$ & $102.8 \pm 15.87$ & $103(93.3-113.8)$ & 59 & 1.8 \\
Activity Regularity Index & $0-9$ & $4.2 \pm 1.28$ & $4.1(3.2-5.2)$ & 7.5 \\
\hline
\end{tabular}


Table 3 - Mean values of hits by activity

\begin{tabular}{|c|c|c|}
\hline & Scale items & Mean \pm SD \\
\hline 1 & I got out of bed & $4.1 \pm 2.9$ \\
\hline 2 & I spoke with another person for the first time (personally or on the telephone) & $4.0 \pm 2.5$ \\
\hline 4 & I had breakfast & $4.2 \pm 2.5$ \\
\hline 5 & The first time I left home & $3.0 \pm 2.6$ \\
\hline 6 & I made physical exercises (walk, gymnastics, dance, etc.) & $2.0 \pm 1.9$ \\
\hline 8 & I had lunch & $6.3 \pm 1.9$ \\
\hline 9 & I took a nap in the afternoon & $2.0 \pm 1.3$ \\
\hline 10 & I had something to eat or drink in the afternoon (write only the first time) & $4.6 \pm 2.3$ \\
\hline 11 & The last time I arrived home & $3.4 \pm 2.5$ \\
\hline 12 & I had dinner & $4.9 \pm 2.3$ \\
\hline 17 & I went to bed & $5.6 \pm 2.0$ \\
\hline
\end{tabular}

The activity with the highest contribution to the regularity index was "I had lunch", similarly to a previous study with an American population, ${ }^{17}$ probably for including employees of the same institution, with fixed times for food availability. However, the items with the highest mode were those related to sleep ("I took a nap in the afternoon" and "I went to bed"). Food and sleep together comprise a group of activities with a strong physiological component, suggesting the participation of biological rhythms in the regularity of social behaviors.

The validity of a scale refers to the instrument ability to measure the intended construct. The content of the Social Rhythm Scale was evaluated by people qualified to judge as to whether the scale items actually represent the subjacent concepts, the adequacy of presentation form and the language to the intended population, as

\section{Table 4 - Matrix of factor analysis}

\begin{tabular}{|c|c|c|c|}
\hline Scale items & \multicolumn{3}{|c|}{ Components } \\
\hline I got out of bed & 0.79 & 0.338 & 0.507 \\
\hline $\begin{array}{l}\text { I listened to the radio or watched TV (at home, in the car, at work or } \\
\text { somewhere else) }\end{array}$ & 0.908 & 0.419 & 0.013 \\
\hline The first time I left home & 0.978 & 0.135 & 0.162 \\
\hline I made physical exercises (walk, gymnastics, dance, etc.) & 0.679 & 0.488 & 0.548 \\
\hline $\begin{array}{l}\text { I started working (or school activity, household chore, voluntary work, } \\
\text { children care or care to other family members, etc.) }\end{array}$ & 0.234 & 0.800 & 0.553 \\
\hline I had lunch & 0.863 & -0.433 & 0.261 \\
\hline I had dinner & 0.941 & 0.331 & -0.069 \\
\hline I performed a leisure activity (watched TV, went to the movies, read, etc.) & 0.518 & 0.850 & 0.093 \\
\hline The last time I turned off the TV or radio & -0.320 & 0.359 & -0.877 \\
\hline ACTIVITY A $\ldots \ldots \ldots \ldots \ldots \ldots \ldots \ldots$ & 0.082 & -0.951 & 0.297 \\
\hline ACTIVITY B ....................... & 0.310 & 0.554 & 0.773 \\
\hline I went to bed & 0.564 & 0.600 & 0.567 \\
\hline
\end{tabular}


well as the relevance or non-relevance of each aspect of the validated instrument. ${ }^{34}$ The fact that no other instrument is available to evaluate the social rhythm makes it difficult to assess the concurrent and convergent validities. The discrimination power of the scale can be evaluated considering studies that compare groups with obviously altered social rhythm, such as postoperative or depressed patients.

Some methodological issues regarding the methodology of this study should be discussed. First, the Brazilian sample is homogeneous and excluded or controlled potentially confounding variables. Second, we controlled some potential measure bias in the application of the test. But unfortunately, an important aspect is the high level of schooling of the Brazilian sample, because previous studies showed that the educational level can influence the outcomes in health and life style assessed by selfreport measures. ${ }^{35-37}$ This should affect the comprehension of questions and, consequently, the answers. As the schooling reflects the socioeconomic aspect in a very close way, the high level of schooling of these subjects suggests that they belong to a higher socioeconomic class than the general Brazilian population, with more cognitive skills, more information resource and accessibility to health care. ${ }^{38}$ Second, all workers are from the same institution, with similar schedules of work. This may be influenced the results of activity regularity. Finally, while the homogenous population of this study is methodologically advantageous, the issue of external validity arises. Therefore, is highly recommended to apply this instrument to different samples to increase the external validity

\section{Conclusion}

The social rhythm scale presents content validity and good testretest reliability. The scores present Gaussian distribution in the studied population. In the studied population, the most robust zeitgeber was the lunch time (with the highest mean of hits), closely followed by the two sleep times: after lunch and night sleep (with the highest mode). The factor analysis divided the scale into three components, unlike the results obtained with the same type of analysis applied to the original English version of the instrument, which showed two domains: activities performed in the first half of the day and activities performed in the second half of the day. Subsequent studies performed with other populations will be important to verify the scale behavior and type of relation between rhythmicity and mental disorders.

\section{Acknowledgements}

We would like to thank Dr. Timothy Monk, from the University of Pittsburgh, for his collaboration to the scale analysis.

\section{Disclosures}

\begin{tabular}{|c|c|c|c|c|c|c|c|}
\hline $\begin{array}{l}\text { Writing group } \\
\text { member }\end{array}$ & Employment & $\begin{array}{c}\text { Research } \\
\text { grant }^{1}\end{array}$ & $\begin{array}{l}\text { Other research grant or } \\
\text { medical continuous } \\
\text { education }\end{array}$ & $\begin{array}{l}\text { Speaker's } \\
\text { honoraria }\end{array}$ & $\begin{array}{l}\text { Ownership } \\
\text { interest }\end{array}$ & $\begin{array}{l}\text { Consultant/ } \\
\text { advisory } \\
\text { board }\end{array}$ & Other $^{3}$ \\
\hline $\begin{array}{l}\text { Regina Lopes } \\
\text { Schimitt }\end{array}$ & UFRGS & FIPE-HCPA* & - & - & - & - & - \\
\hline Talita Zanetti & FFFCMPA & FIPE-HCPA* & - & - & - & - & - \\
\hline $\begin{array}{l}\text { Cristiane } \\
\text { Koplin }\end{array}$ & PUC-RS & FIPE-HCPA* & - & - & - & - & - \\
\hline $\begin{array}{l}\text { Fabiana } \\
\text { Guarienti }\end{array}$ & UFRGS & FIPE-HCPA* & - & - & - & - & - \\
\hline $\begin{array}{l}\text { Maria Paz } \\
\text { Hidalgo }\end{array}$ & UFRGS & FIPE-HCPA* & - & - & - & - & - \\
\hline
\end{tabular}

References

1. Marques N, Menna-Barreto L. Cronobiologia: princípios e aplicaçōes. 3a edição. 2003. p.60-5.

2. Aschoff J, Fatranská M, Giedke H, Doerr P, Stamm D, Wisser H. Human circadian rhythms in continuous darkness: entrainment by social cues. Science. 1971;171(967):213-5.

3. Monk TH, Petrie SR, Hayes AJ, Kupfer DJ. Regularity of daily life in relation to personality, age, gender, sleep quality and circadian rhythms. J Sleep Res. 1994;3(4):196-205.
4. Monk TH, Frank E, Potts JM, Kupfer DJ. A simple way to measure daily lifestyle regularity. J Sleep Res. 2002;11(3):183-90.

5. Wehr TA, Goodwin FK. Biological rhythms in maniac-depressive illness. In: Wehr TA, Goodwin FK, editors. Circadian rhythms in psychiatry. Pacific Grove, CA: The Boxwood Press; 1983. p.129-84.

6. Kripke DF. Phase-advance theories for affective illness. In: Wehr TA, Goodwin FK, editors. Circadian rhythms in psychiatry. Pacific Grove, CA: The Boxwood Press; 1983. p.41-69. 
7. Gillin JC, Mendelson WB, Kupfer DJ. The sleep disturbances of depression: clues to pathophysiology with special reference to the circadian rapid eye movement rhythm. In: Kupfer DJ, Monk TH, Barchas JD, editors. Biological rhythms and mental disorders. New York: Guilford Press; 1988.

8. Krieger DT. Abnormalities in circadian periodicity in depression. In: Kupfer DJ, Monk TH, Barchas JD, editors. Biological rhythms and mental disorders. New York: Guilford Press; 1988. p.177-95.

9. Vernikos-Danellis J, Winget CM. The importance of linght, postural and social cues in the regulation of the plasma cortisol rhythm in man. Chronopharmacology: proceedings of the satellite symposium of the 7 th international congress of pharmacology. Paris, France; 1979. p.101-6.

10. Winget CM, Vernikos-Danellis J, Beljan JR. Synchrony of the physiological rhythms is regulated by social zeitgebers. Physiologist. 1975;18:1025.

11. Brown GW, Harris T. Social origins of depression. New York: The Free Press; 1978.

12. Dohrenwend BS, Dohrenwend BP. Life stress and psychopathology. In: Regier DA, Allen G editors. Risk factor research in the major mental disorders. National Institute of Mental Health. DHHS Pub. No. (ADM). 81-1068. Washington DC: Supt of Docs, US. Govt. Print Off; 1981.

13. Ezquiaga E, Ayuso Gutierrez JL, García López A. Psychosocial factors and episode number in depression. J Affect Disord. 1987;12(2):135-8.

14. Ehlers CL, Frank E, Kupfer DJ. Social zeitgebers and biological rhythms. A unified approach to understanding the etiology of depression. Arch Gen Psychiatry. 1988;45(22):948-52.

15. Grandin LD, Alloy LB, Abramson LY. The social zeitgeber theory, circadian rhythms, and mood disorders: review and evaluation. Clin Psychol Rev. 2006;26(6):679-94.

16. Monk TH, Kupfer DJ, Frank E, Ritenour AM. The social rhythm metric (srm): measuring daily social rhythms over 12 weeks. Psychiatry Res. 1990;36(2):195-207.

17. Monk TH, Flaherty JF, Frank E, Hoskinson K, Kupfer DJ. The social rhythm metric - an instrument to quantify the daily rhythms of life. J Nerv Ment Dis. 1990;178(2):120-6.

18. Monk TH, Essex MJ, Snider NA, Klein MH, Lowe KK, Kupfer DJ. The impact of the birth of a baby on the time structure and social mixture of a couple's daily life and its consequences for well-being. J Appl Soc Psychol. 1996;26:1237-58.

19. Brown LF, Reynolds CF 3rd, Monk TH, Prigerson HG, Dew MA, Houck PR, Mazumdar S, Buysse DJ, Hoch CC, Kupfer DJ. Social rhythm stability following late-life spousal bereavement: associations with depression and sleep impairment. Psychiatry Res. 1996;62(2):161-9.

20. Monk TH, Reynolds CF 3rd, Machen MA, Kupfer DJ. Daily social rhythms in the elderly and their relation to objectively recorded sleep. Sleep. 1992;15(4):322-9.

21. Szuba MP, Yager A, Guze BH, Allen EM, Baxter LR Jr. Disruption of social circadian rhythms in major depression: a preliminary report. Psychiatry Res. 1992;42(3):221-30.

22. Shear MK, Randall J, Monk TH, Ritenour A, Tu X, Frank E, Reynolds C, Kupfer DJ. Social rhythm in anxiety disorder patients. Anxiety. 1994;1(2):90-5.

23. Campos TF, Galvão Silveira AB, Miranda Barroso MT. Regularity of daily activities in stroke. Chronobiol Int. 2008;25(4):611-24.

24. Frank E. Treating bipolar disorder. New York: Guilford Press; 2005.

25. Frank E, Kupfer DJ, Thase ME, Mallinger AG, Swartz HA, Fagiolini AM, Grochocinski V, Houck P, Scott J, Thompson W, Monk TH. Two years outcomes for interpersonal and social rhythm therapy in individuals with bipolar disorder. Arch Gen Psychiatry. 2005;62(9):996-1004.

26. Herdman M, Fox-Rushby J, Badia X. A model of equivalence in the cultural adaptation of hrqol instruments: the universalist approach. Qual Life Res. 1998;7(4):323-35.

27. Moraes CL, Hasselmann MH, Reichenheim ME. Adaptação transcultural para o português do instrumento "revised conflict tatics scales (cts2)» utilizado para identificar violência entre casais. Cad Saude Publica. 2002;18(1):167-76.

28. Hair JF, Anderson RE, Tatham RL, Black WC. Multivariate data analysis (with readings). 4th ed. New Jersey: Prentice Hall, Englewood Cliffs; 1995.

29. Reis E. Estatística multivariada aplicada. Lisboa:Ediçōes Sílabo: 1997.

30. Artes R. Aspectos estatísticos da análise fatorial de escalas de avaliação. Rev Psiquiatr Clin. 1998;25(5):223-8.

31. Hidalgo MP, Caumo W. Sleep disturbances associated with minor psychiatric disorders in medical students. Neurol Sci. 2002;23(1):35-9.

32. Rowland D, Arkkelin D, Crisler L. Computer-based data analysis: using SPSS in the social and sciences. Chicago: Wardsworth Pub Co; 1991. Nelsonhall Series in Psychology.

33. Indicadores Sociais Mínimos do Instituto Brasileiro de Geografia e Estatística. [citado 29 julho 2009]. Available from: http://www.ibge.gov.br/home/ estatistica/populacao/condicaodevida/indicadoresminimos/tabela3.shtm

34. Fachel JMG, Camey S. Avaliação psicométrica: a qualidade das medidas e o entendimento dos dados. In: Cunha JA, organizador. Psicodiagnóstico V. 5 ed. rev e ampl. Porto Alegre: Artmed; 2000. p.158-70.

35. Grassi-Oliveira R, Stein LM, Pezzi JC. Translation and content validation of the Childhood Trauma Questionnaire into Portuguese language. Rev Saude Publica. 2006;40(2):249-55.

36. Reichenheim ME, Moraes CL, Hasselmann MH. Semantic equivalence of the Portuguese version of the Abuse Assessment Screen tool used for the screening of violence against pregnant women. Rev Saude Publica. 2000;34(6):610-6.

37. Pasquali L. Princípios de elaboração de escalas psicológicas. In: Gorestein C, Andrade LHSG, Zuardi AW, editors. Escalas de avaliação clínica em psiquiatria e psicofarmacologia. São Paulo: Lemos; 2000. p.15-21.

38. Monteiro CA, Conde WL, de Castro IR. The changing relationship between education and risk of obesity in Brazil (1975-1997). Cad Saude Publica. 2003;19 Suppl 1:S67-75. 


\section{Appendix - Instructions for the Social Rhythm Scale score calculation}

If data are entered in MICROSOFT $®$ EXCEL 2000, or its variations:

All cells should be formatted as time (Format - cells - number - time).

Create a grid with the activities in the vertical columns (column A) and the days in the horizontal column (line 1). Enter the time each activity was performed in $\mathrm{B} 2$ to $\mathrm{J} 18$ (for nine-day activity) of the spreadsheet.

At the end, calculate the mean time and the standard deviation at each activity was performed. It can be done with the insertion of MEAN and STANDARD DEVIATION functions.

Ex: activity 1:

Day $01-09: 00$

Day $02-07: 00$

Day 03-07:30

Day $04-07: 30$

Day $05-07: 30$

Day $06-07: 30$

Day $07-07: 30$

Day $08-09: 00$

Day $09-08: 10$

Mean: 07:51

Standard deviation: 0:42

Calculate the min. and max. limits around the mean value to determine the exceeding values. Exceeding values represent the activities that occur out of the 1.5 standard deviation around the mean value.

The formulas are:

Min. time $=$ mean time $-(1.5 \times$ standard deviation $)$

Max. time $=$ mean time $+(1.5 \times$ standard deviation $)$

In the example above:

Min. time $=07: 51-(1.5 \times 0: 42)=06: 46$

Max. time $=07: 51+(1.5 \times 0: 42)=08: 55$

Then, all values that exceeded the interval from 06:46 to 08:55 should be removed. Excel can identify the exceeding values through function SE. To see, for instance, if the time entered in cell B2 (activity 1, day 1) is an exceeding value, assuming the min. time is in cell M2 and max. time is in cell $N 2$, the following formula is applied: $=S E(E(B 2>=\$ M 2 ; B 2<=\$ N 2) ; B 2 ; " ')$, and then successively cell by cell. This function will reproduce all the grid of times, leaving blank cells in case of exceeding values.

Based on this new grid, without exceeding values, recalculate the mean time. This is the habitual time of the activity. In the example above, the new mean is 07:31. Now, it is necessary to determine the hits, i.e., the activities that occur within a max. period of 45 minutes before and 45 minutes after the mean time. The formula is:

Min. hit limit=new mean -45 minutes

Max. hit limit=new mean +45 minutes

In the example above:

Min. hit limit=07:31-00:45=06:46

Max. hit limit=07:31+00:45=08:16, i.e., the hit will fall within the interval from 06:46 and 08:16.

Select all activities that occurred at least three times a week, which are those with hit possibility, and add up the days on which these activities were performed. It is possible to do it at Excel, using COUNT function, establishing a column of possible hits. Assuming that data are in space $\mathrm{O} 2: \mathrm{W} 18$, the count is performed, line by line, entering in the first cell of the column of possible hits =COUNT(O2:W2), in the second cell $=$ COUNT(O3:W3) and then successively. At the end of the column, it is possible to count only the values of 3 or above, using COUNT IF function. If the column of possible hits is from $A B 2$ to $A B 18$, for instance, enter in the result cell: $=C O N T . S E(A B 2: A B 18 ; ">2 ")$. It will provide the quantity of days with possible hits.

Count of hits. Example: 
Grid of times: O2:W18 space

Min. hit limit: column $Y$

Max. hit limit: column Z

Calculation of values for line 2 :

$=A D D P R O D U C T(N(O 2: W 2>=Y 2) ; \mathrm{N}(\mathrm{O} 2: \mathrm{W} 2<=\mathrm{Z} 2))$. It is recommended to "lock" the column. After that, perform the simple sum of values.

In the example above of 17 activities, 14 of them occurred at least three times a week:

\begin{tabular}{|l|l|l|}
\hline Activity & Days with possible hits & hits \\
\hline 1 & 7 & 7 \\
\hline 2 & 8 & 7 \\
\hline 3 & 7 & 6 \\
\hline 4 & 7 & 6 \\
\hline 5 & 8 & 6 \\
\hline 7 & 8 & 8 \\
\hline 8 & 8 & 8 \\
\hline 10 & 8 & 6 \\
\hline 11 & 8 & 6 \\
\hline 12 & 6 & 6 \\
\hline 13 & 7 & 4 \\
\hline 14 & 8 & 3 \\
\hline 15 & 3 & 6 \\
\hline 17 & 8 & Total = 86 \\
\hline \multicolumn{2}{|l|}{ Social rhythm score=total hits by activities/number of activities that occurred at least three times a week } \\
\hline Social rhythm score $=86 / 14=6.14$ & \\
\hline
\end{tabular}

The Total Score of Activities (ETA) is obtained with the simple count of total activities performed. If data are, for instance, in B2:J18 space of Excel spreadsheet, this count can be performed by entering the formula =COUNT (B2:J18). 